\title{
Histochemical Activities of Hydroxysteroid Dehydrogenases and Lipids in the Goat Corpus Luteum during Late Pregnancy
}

Hajime Mryamoto and Takehiko IshIbashi

Department of Animal Science, Faculty of Agriculture, Kyoto University, Kyoto-shi 606

(Received June 13, 1981)

\begin{abstract}
The histochemistry of lipids, NADH and NADPH dehydrogenases, $\Delta^{5}-3 \beta-$, $3 \alpha^{-}, 11 \beta-, 17 \beta-, 20 \alpha-$ and $20 \beta$-hydroxysteroid dehydrogenases (HSD) has been studied in the goat corpus luteum during late pregnancy. The activity of lipids was moderate with Sudan black B and weak with oil red O. The activities of NADH and NADPH dehydrogenases were very strong. The $3 \beta-H S D$ activity, when pregnenolone was used as substrate, was moderate. When dehydroepiandrosterone was used, the activity was strong. The $3 \alpha-\mathrm{HSD}$ activity was observed to be weak. The enzymes $11 \beta, 17 \beta-, 20 \alpha$ and $20 \beta-\mathrm{HSD}$ were not detectable in the corpus luteum. These results suggest that the goat corpus luteum can synthesize progesterone during late pregnancy. The present histochemical findings seem to be correlated with the importance of the corpus luteum for the maintenance of pregnancy in the goat.
\end{abstract}

Jpn. J. Zootech. Sci., 53 (2): 93-98, 1982

Ovariectomy or removal of the corpora lutea at any time during pregnancy will lead to the termination of pregnancy in the cow, pig and goat unless appropriate replacement therapies with progesterone or estrogen are initiated, except for the sheep in which the presence of the corpus luteum is not essential during the second half of pregnancy ${ }^{1,2)}$. Plasma progesterone of pregnant goats was measured ${ }^{3-6)}$. Plasma progesterone levels in the ovarian or peripheral venous blood increased gradually by the 90 th day of pregnancy and then fell ${ }^{5}$. Plasma estrogens in pregnant goats were also determined and the levels increased steadily with advancing pregnancy ${ }^{\theta}$.

Since the histochemical activities in the ovary correlate fairly well with the biochemical results ${ }^{7}$, the histochemical demonstration of steroidogenic enzyme activities has been made to aid the interpretation of the ovarian function. Some histochemical studies on the ovaries of pregnant farm animals have been reported ${ }^{7-14}$. However, the histochemical demonstration of the hydroxysteroid dehydrogenase activity in the pregnant goat ovary has not been reported except for one investigation ${ }^{19}$ in which the observed ovaries were only of very early pregnancy. The purpose of the present in vestigation was to examine the activity of hydroxysteroid dehydrogenases and lipids (steroid hormone precursors) in the goat corpus luteum during late pregnancy.

\section{Materials and Methods}

Japanese native goats were used in this study. The ovaries were obtained from Jpn. J. Zootech. Sci., 53 (2): 93-98 
three goats at 110-130 th day of pregnancy. They were immediately frozen in prechilled isopentane and stored with dry ice until the histochemical procedures were performed. They were sectioned at $15 \mu \mathrm{m}$ in a cryostat maintained at about $-20^{\circ} \mathrm{C}$ and the sections were mounted on glass slides.

The activities of the following steroidogenic enzymes were studied: $\Delta^{5}-3 \beta-(3 \beta-$ HSD), $3 \alpha-(3 \alpha-\mathrm{HSD}), \quad 11 \beta-(11 \beta-\mathrm{HSD}), \quad 17 \beta-(17 \beta-\mathrm{HSD}), 20 \alpha-(20 \alpha-\mathrm{HSD})$ and $20 \beta$-hydroxysteroid dehydrogenases (20 $\beta$-HSD). Hydroxysteroid dehydrogenases, substrates and cofactors are shown in Table 1 . The sections were incubated at $37^{\circ} \mathrm{C}$

Table 1. Histochemical methods for dehydrogenases

\begin{tabular}{|c|c|c|c|}
\hline Dehydrogenase & Substrate & Cofactor & Reference \\
\hline NADH dehydrogenase & $\mathrm{NADH}$ & - & BARKA and ANDERSON ${ }^{15}$ ) \\
\hline NADPH dehydrogenase & NADPH & - & BARKA and ANDERSON ${ }^{15)}$ \\
\hline $3 \beta-\mathrm{HSD}$ & pregnenolone & NAD & BlaHa and LeAvitT ${ }^{16)}$ \\
\hline $3 \beta-H S D$ & dehydroepiandrosterone & NAD & WATTENBERG ${ }^{17}$ \\
\hline $3 \alpha-\mathrm{HSD}$ & androsterone & N A D & Fowler and FeLdMAN ${ }^{18)}$ \\
\hline $11 \beta-\mathrm{HSD}$ & androstenedione & NAD & BAILLIE et $a l .^{19)}$ \\
\hline $17 \beta-\mathrm{HSD}$ & estradiol-17 $\beta$ & NAD & IsHida and NIImura ${ }^{20}$ \\
\hline $17 \beta-\mathrm{HSD}$ & testosterone & NAD & IsHIDA and NIIMURA ${ }^{20}$ \\
\hline $20 \alpha-\mathrm{HSD}$ & $20 \alpha$-dihydroprogesterone & NADP & BALOGH ${ }^{21)}$ \\
\hline $20 \beta$-HSD & $20 \beta$-dihydroprogesterone & NAD & BaLLLIE ${ }^{22)}$ \\
\hline
\end{tabular}

for $1 \mathrm{hr}$. Then the sections, except for $17 \beta-\mathrm{HSD}$, were fixed in $10 \%$ neutral formalin. Those for $17 \beta$-HSD were fixed in $80 \%$ alcohol. All series of sections were mounted with glycerol. The control sections were incubated in a medium without any steroidal substrate.

Since NADH and NADPH dehydrogenases are prerequisites for the histochemical localization of NAD- and NADP-linked dehydrogenases, the activity of these dehydrogenases was also determined by the method of BARKA and ANDERSON ${ }^{15}$. Lipids were stained with Sudan black B or oil red $O$. The activity of enzyme reaction was expressed as 0 (negative), 1 (very weak), 2 (weak), 3 (moderate), 4 (strong), and 5 (very strong).

\section{Results}

The activities of lipids and dehydrogenases in the goat corpus luteum during late pregnancy are summarized in Table 2. The activity of lipids was moderate with Sudan black B (Fig. 1) and weak with oil red $O$. The corpus luteum contained only moderate sparse lipids and did not show the accumulation of coarse lipid droplets (Fig. 1). The activities of NADH (Fig. 2) and NADPH dehydrogenases were very strong.

The $3 \beta$-HSD activity with pregnenolone as substrate was moderate (Figs. 3, 4) and the activity with dehydroepiandrosterone was strong (Fig. 5). The $3 \beta$-HSD activity in the ovary was restricted to the corpus luteum except for the theca interna 
Table 2. Histochemical activity of dehydrogenases and lipids in the goat corpus luteum during late pregnancy

\begin{tabular}{|c|c|c|}
\hline \multicolumn{2}{|c|}{ Dehydrogenase/lipid } & Activity \\
\hline \multirow{2}{*}{ Lipids } & Sudan black B & 3 \\
\hline & oil red $\mathrm{O}$ & 2 \\
\hline \multirow{10}{*}{ Dehydrogenases } & NADH dehydrogenase (NADH) & 5 \\
\hline & NADPH dehydrogenase (NADPH) & 5 \\
\hline & $3 \beta-\mathrm{HSD}$ (pregnenolone) & 3 \\
\hline & $3 \beta$-HSD (dehydroepiandrasterone) & 4 \\
\hline & $3 \alpha-\mathrm{HSD}$ (androsterone) & 2 \\
\hline & $11 \beta$ HSD (androstenedione) & 0 \\
\hline & $17 \beta$-HSD (estradiol-17 $\beta$ ) & 0 \\
\hline & $17 \beta$-HSD (testosterone) & 0 \\
\hline & 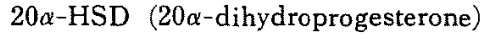 & 0 \\
\hline & $20 \beta$-HSD (20 $\beta$-dihydroprogesterone) & 0 \\
\hline
\end{tabular}

The enzyme activity was rated on an arbitrary scale from 0 to $5: 0$ (negative), 1 (very weak), 2 (weak), 3 (moderate), 4 (strong) and 5 (very strong).

of antral follicles in which very weak activity was observed. This enzyme was most active hydroxysteroid dehydrogenase encountered in the present study. The $3 \alpha-\mathrm{HSD}$ activity was found to be weak (Fig. 6). The enzymes $11 \beta^{--}, 17 \beta^{-}, 20 \alpha^{-}$and $20 \beta^{-}$ HSD were not detectable in the corpus luteum. To the contrary, the $17 \beta$-HSD was weakly present in the granulosa cells and theca interna of antral follicles.

\section{Discussion}

In many farm animals including the goat, the ovary is the main source of progesterone sesretion during late pregnancy ${ }^{4,5.23}$ and can not be removed at any stage of pregnancy without causing abortion ${ }^{1,2,24}$. However, in the sheep the placenta is the main source of progesterone during late pregnancy ${ }^{4,5}$.

The enzyme $3 \beta-H S D$ is active in the conversion of pregnenolone to progesterone and in the conversion of dehydroepiandrosterone to androstenedione. The occurrence of moderate $3 \beta-\mathrm{HSD}$ activity with pregnenolone as substrate in the corpus luteum, therefore, suggests the capacity of goat corpus luteum during late pregnancy to synthesize progesterone. In the present study $3 \beta-\mathrm{HSD}$ activity in the ovary was restricted to the corpus luteum except for the theca interna of antral follicles in which very weak activity was observed. These histochemical results suggest that the corpus luteum is the major site of progesterone production among the ovarian components in the late pregnant goat. The results are consistent with the presence of plasma progesterone in the ovarian venous blood found by biochemical methods ${ }^{3-5}$ ) and with the importance of the corpus luteum for the maintenance of pregnancy in the goat ${ }^{24}$.

The corpus luteum contained only moderate sparse lipids. Since the accmulation of coarse lipid droplets in steroid hormone-producing glands is usually thought to be 
inversely related to secretory activity ${ }^{25)}$, the absence of coarse lipid droplets in this study may suggest the active function of the goat corpus luteum during late pregnancy. Since lipids are steroid hormone precursors, these results may be related to the presence of $3 \beta-\mathrm{HSD}$ activity in the corpus luteum and plasma progesterone in the ovarian venous

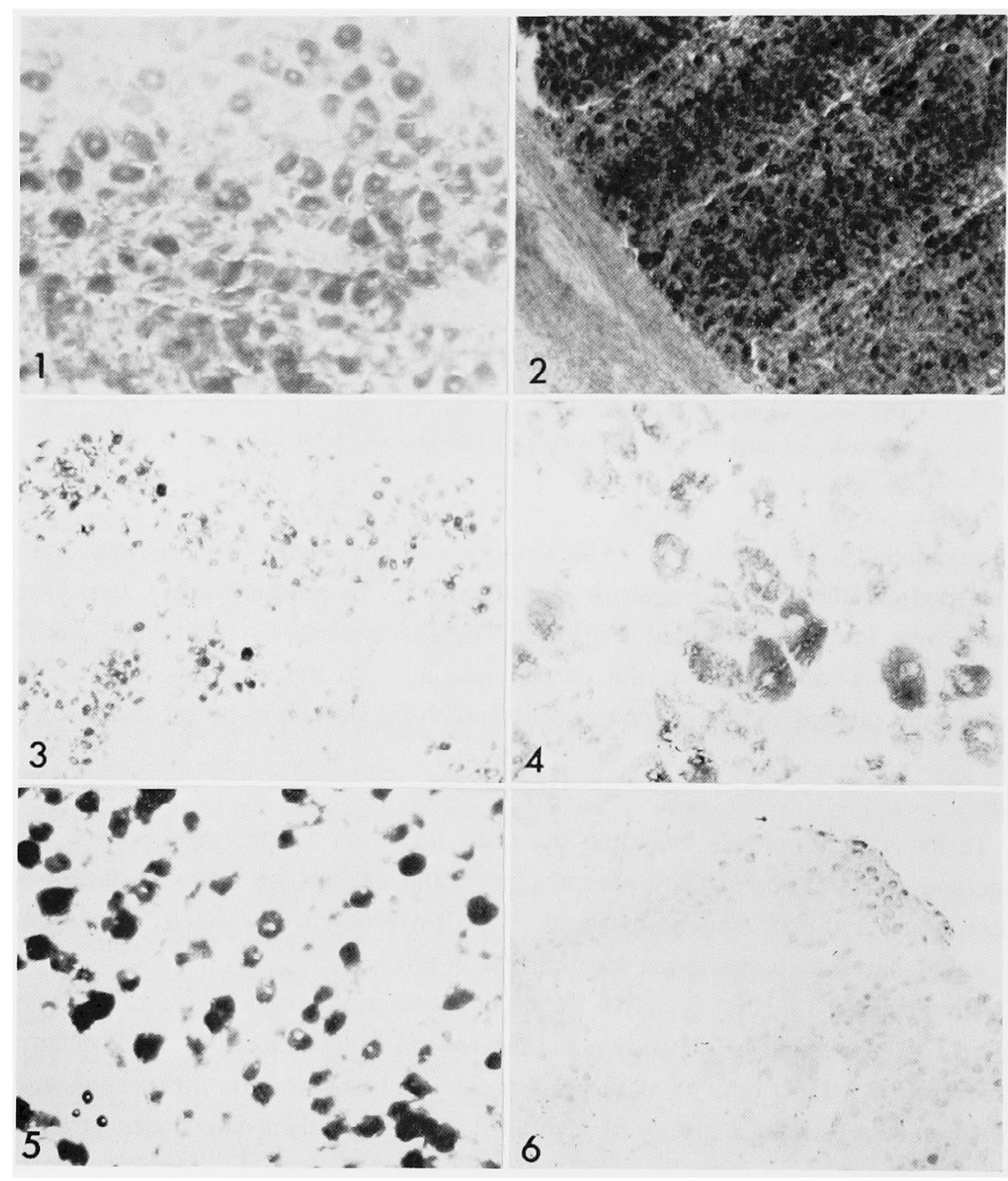

\section{Explanation of Figures}

Enzymatic preparations of goat corpus luteum during late pregnancy.

Fig. 1. Corpus luteum showing moderate lipid activity. Only sparse lipids are present. Note the absence of the accumulation of lipid droplets. Stained with Sudan black B. $\times 100$.

Fig. 2. Very strong NADH dehydrogenase activity is observed. $\times 40$.

Fig. 3. Moderate $3 \beta-\mathrm{HSD}$ activity when pregnenolone is used as substrate. $\times 40$.

Fig. 4. A high magnification $(\times 200)$ of Fig. 3 . Moderate $3 \beta-H S D$ activity is seen in the cytoplasm of luteal cells. No staining of the nuclei.

Fig. 5. Strong $3 \beta-\mathrm{HSD}$ activity when dehydroepiandrosterone is used as substrate. $\times 100$.

Fig. 6. Weak $3 \alpha$-HSD activity is observed. $\times 40$. 
blood during late pregnancy in the goat ${ }^{3-5}$ ).

The enzyme $3 \alpha$-HSD influences steroidogenesis and catalyses reversibly the interconversion of androsterone and androstanedione. The weak activity of this enzyme in the goat corpus luteum during late pregnancy seems to show that a weak androgen metabolism is occurring in these luteal cells.

Plasma estrogen levels in pregnant goats increased steadily with advancing pregnancy ${ }^{6)}$. The enzyme $17 \beta$-HSD is reversibly active in the interconversion of estradiol-17 $\beta$ and estrone, or of testosterone and androstenedione. This enzyme was not detectable in the corpus luteum in this study, suggesting the lack of capacity of the corpus luteum to synthesize estrogens. As the granulosa cells and theca interna of antral follicles in the late pregnant goat exhibited weak $17 \beta$-HSD activity, antral follicles are likely to contribute to estrogen synthesis.

The ovary of the cow and pig produces $20 \beta$-dihydroprogesterone, while that of the sheep produces $20 \alpha$-dihydroprogesterone ${ }^{23}$. Furthermore, $20 \beta$-dihydroprogesterone was identified in the corpus luteum of the cow and pig $^{23}$. The interconversion of $20 \alpha$-dihydroprogesterone and progesterone is catalyzed by $20 \alpha-\mathrm{HSD}$ and that of $20 \beta$-dihydroprogesterone and progesterone by $20 \beta$-HSD.

Davies $e t$ al. ${ }^{26}$ ) reported no $20 \alpha$ - and $20 \beta$-HSD activity in the cow corpus luteum whereas LOBEL and LEVY' ${ }^{10)}$ observed the occurrence of $20 \beta$-HSD in the cow corpus luteum. No positive $20 \alpha$ - and $20 \beta$-HSD activities were obtained in this study. The negative histochemical activities in the corpus luteum in this study could not be explained by lack of tetrazolium reductase ${ }^{7}$, as both NADH and NADPH dehydrogenase activities were obtained. As very weak $20 \alpha$-HSD activity was observed in the nonpregnant goat corpus luteum (unpublished data), perhaps these enzyme activities in the goat corpus luteum during late pregnancy were too weak to be detected with the histochemical method used, or the corpus luteum during late pregnancy lacked any of these enzymes.

\section{References}

1) Catchpole, H. R., in Reproduction in Domestic Animals. 3 rd ed. (Cole, H. H. and P. T. Cupps, eds.) 341-368. Academic Press. New York. 1977.

2) Robertson, H. A., in Reproduction in Domestic Animals. 3 rd ed. (Cole, H. H. and P.T. Cupps, eds.) 475-498. Academic Press. New York. 1977.

3) Raeside, J. I. and C. W. Turner, J. Dairy Sci., 38: 1334-1343. 1955.

4) Linzell, J. L. and R. B. HeAP, J. Endocr., 41: 433-438. 1968.

5) Blom, A. K. and O. Lyngset, Acta Endocr., 66: 471-477. 1971.

6) Challis, J.R.G. and J. L. Linzell, J. Reprod. Fert., 26: 401-404. 1971.

7) Bjersing, L., Histochemie, 10; 295-304. 1967.

8) Foley, R. C., R. P. Reece and J. H. Leathem, J. Anim. Sci., 13: 131-137. 1954.

9) Rubin, B. L., H. W. Deane and J.A. Hamilton, Endocrinology, 73: 748-763. 1963.

10) Lobel, B. L. and E. Levy, Acta Endocr., 59: Suppl. 132: 1-63. 1968.

11) Nakama, S., Bull. Univ. Osaka Pref., Ser. B, 28: 19-98. 1976.

12) Goode, L., A.C. Warnick and H. D. Wallace, J. Anim. Sci., 24: 955-958. 1965.

13) Miyamoto, H., M. Irie, T. Ishibashi and K. Utsumi, Jpn. J. Zootech. Sci., 50: 870-878. 1979.

14) Miyamoto, H., T. Ishibashi and K. Utsumi, Jpn. J. Zootech. Sci., 51 : 582-587. 1980.

15) Barka, T. and P. J. Anderson, in Histochemistry. 296-333. Harper and Row Publishers. New York. 1963. 


\section{Miyamoto and Ishibashi}

16) Blaha, G.C. and W.W. Leavitt, Biol. Reprod., 3: 362-368. 1970.

17) WattenberG, L. W., J. Histochem. Cytochem., 6: 225-232: 1958.

18) Fowler, E. H. and M. K. Feldman, Gen. Comp. Endocr., 14: 484-490. 1970.

19) Ballite, A. H., M. M. Ferguson, K. C. Calman and D. McK. Hart, J. Endocr., 33: 119-125. 1965.

20) Ishida, K. and S. Nilmura, Jpn. J. Zootech. Sci., 48: 373-375. 1977.

21) BALOGH, K., J. Histochem. Cytochem., 12: 670-673. 1964.

22) Baillie, A. H., K. C. Calman, M. M. Ferguson and D. McK. Hart, J. Endocr., 32: 337-339. 1965.

23) Henricks, D. M. and D. T. Mayer, in Reproduction in Domestic Animals. 3 rd ed. (Cole, H. H. and P. T. Cupps, eds.) 79-117. Academic Press. New York. 1977.

24) Meites, J., H. D. Webster, F. W. Young, F. Thorp, Jr. and R. N. Hatch, J. Anim. Sci, 10: 411-416. 1951.

25) Deane, H. W., M. F. HaY, R. M. Moor, L. E. A. Row son and R. V. Short, Acta Endocr., 51: 245-263. 1966.

26) Davies, J., G. R. Dayenport, J. L. Norris and P. I. C. Rennie, Endocrinology, 78: 667-671. 1966.

\section{妊娠後期山羊黄体のステロイド水酸基・脱水素 酵素之脂質活性}

宮本元・石橋武㢁

京都大学農学部，京都市 606

妊娠後期の山羊卵巣におけるステロイドホルモン合成 に関して検討するために, 姡娠 110～130日の在来種山羊 黄体ゆのステロイド水酸基・脱水索酵索 (HSD) と脂質

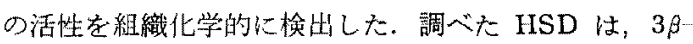
（基質は pregnenolone または dehydroepiandrosterone), $3 \alpha$-(androsterone), $11 \beta$-(androstenedione) , $17 \beta$ -

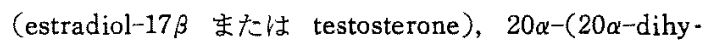

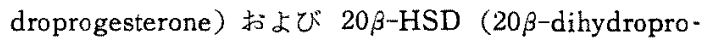
gesterone)であった.なお，HSDの組織化学的反忘性， NADH また性 NADPH 脱水菜酩素に依存しているの で，これらの醅素活性についても検討した，黄体中の脂 質活性は, Sudan black B では中等度であり, oil red O
では弱かった. NADH と NADPH 脱水素酵素の活性注

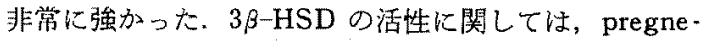
nolone を基質として用いると中等度の活性があり， dehydroepiandrosterone 基とすると强い活性が

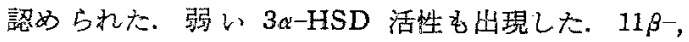

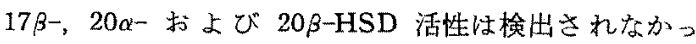
た。これらの成績恃, 妊娠後期の山羊黄体が progesterone の合成能をるっていることを示し，山羊の好娠維持 には黄体が必要であるという，これまでの寒験結果と一 致していると思われる。

日畜会報， $53(2) ： 93-98,1982$ 